\title{
Analysis Of Three Layer Concentric Tube Heat Exchange Using Mathematic Modeling
}

\author{
Rinaldy Valendry \\ Faculty Of Engineering, University Of North Sumatra, Jl. Dr. Mansur No. 9 Padang Bulan, Kec. Medan Baru, \\ Kota Medan 20222
}

\begin{abstract}
ART ICLE INFO
Article history:

Received Aug 05, 2021

Revised Sep 20, 2021

Accepted Oct 30, 2021

Keywords:

Heat Exchanger

Double Concentric Pipe Triple Concentric Pipe

ABSTRACT

A three-channel concentric pipes heat exchanger is a development or improvement of a two-channel concentric heat exchange apparatus. This study was conducted to determine the output temperature of each channel, and compare the results of theoretical calculations using mathematical modeling of experimental results conducted in the field. So that obtained difference of value between result of experiment to result of theory calculation. In this study have 3 variations of temperature data that is $50{ }^{\circ} \mathrm{C}, 55^{\circ} \mathrm{C}$, and $60{ }^{\circ} \mathrm{C}$ with two streams namely CounterFlow and PararellFLow and discharge $2.5 \mathrm{l} /$ minute, while cold fluid with $25{ }^{\circ} \mathrm{C}$ discharge $1.5 \mathrm{l} /$ minute. From the above analysis it can be concluded that the temperature of the hot fluid coming out of the APK in the experiment tends to be higher than the temperature of the hot fluid coming out of the APK on theoretical calculations of mathematical modeling methods. Meanwhile, the cold cold fluid temperature coming out of the APK in experimental tends to be lower than the temperature of the cold fluid coming out of the APK on theoretical calculations of mathematical modeling methods.
\end{abstract}

access article under the CC BY-NC license.

\section{Corresponding Author:}

Rinaldy Valendry,

Faculty Of Engineering,

University Of North Sumatra,

Jl. Dr. Mansur No. 9 Padang Bulan, Kec. Medan Baru, Kota Medan 20222.

Email : rinaldyvalendry@gmail.com

\section{INTRODUCTION}

Along with the times, the era of globalization cannot be avoided, which is marked by the emergence of various kinds of technology that are useful for making it easier for humans to carry out various activities. This technology was created not only to facilitate human work, but also to increase economic value which has an impact on the level of human welfare itself. It is undeniable that the development of the times also has an impact on human needs.

In the industrial world, a tool called a heat exchanger is very widely used. Various types of heat exchangers are used to achieve the desired purpose, such as to heat the product or to cool the product. To develop technology, especially heat exchangers, therefore in this case it is necessary to engineer the technology of heat exchangers, in this case also carried out the development of a heat exchanger with a three-layer type of concentric tube (triple concentric tube heat exchanger), this type has advantages in In terms of effectiveness and efficiency of performance of this type of heat exchanger, double tube heat exchanger, therefore this type of heat exchanger needs to be developed and researched further. In its development the heat exchanger undergoes a shape 
transformation which aims to increase efficiency in accordance with its work function. Heat exchanger is an important medium in the industrial world. For this reason, in this final project, a triple concentric tube heat exchanger model that functions as a water heater and cooler is planned but still refers to the existing design rules. So that it can be used as a learning method regarding the design process, working mechanism, and heat exchanger performance

\section{RESEARCH METHOD}

The data processing is carried out in several parts, where the data obtained from the test will be calculated for its effectiveness value using a formula.

After the test is complete, the data to be processed will be obtained, where the data recorded by the Thermocouple is still raw data to be processed so as to obtain the effectiveness value of each test.

\section{RESULTS AND DISCUSSIONS}

\subsection{Counter Flow flow analysis}

In calculating the data, this research was carried out using mathematical modeling methods to find the value of the three APK pipes. By using the equation in chapter 2, the data needed are , debit, radius of each pipe, , and $\mathrm{h}$. The data was obtained from the experiments carried out.

Table 1.Calculation Data

\begin{tabular}{ccccccc}
\hline Pipe & $(\mathrm{K})$ & Debit $(\dot{\mathrm{m}})$ & Finger $(\mathrm{r})$ & & $\mathrm{h}$ \\
\hline 1 & 298 & $0.0249 / \mathrm{s} \mathrm{X}$ & $1.27 \mathrm{X} \mathrm{m}$ & $4.180 \mathrm{~kJ} / \mathrm{kg} . \mathrm{K}$ & $509,7237 \mathrm{~W} / . \mathrm{K}$ & $?$ \\
2 & 333 & $0.0415 / \mathrm{s} \mathrm{X}$ & $2.54 \mathrm{X} \mathrm{m}$ & $4.185 \mathrm{~kJ} / \mathrm{kg} . \mathrm{K}$ & $1123.08 \mathrm{~W} / . \mathrm{K}$ & $?$ \\
3 & 298 & $0.0249 / \mathrm{s} \mathrm{X}$ & $4.45 \mathrm{X} \mathrm{m}$ & $4.180 \mathrm{~kJ} / \mathrm{kg} . \mathrm{K}$ & $773.46 \mathrm{~W} / . \mathrm{K}$ & $?$ \\
\hline
\end{tabular}

\subsection{Graph Analysis Theory and Experiment Counter Flow}

After calculating for the three variations of the hot fluid inlet, the results of these calculations can be presented in the following table:

Table 2. theoretical calculation results and the results of the 1 Counter Flow Pipe Experiment

\begin{tabular}{ccc}
\hline$\left({ }^{\circ} \mathrm{C}\right)$ & Theory $\left({ }^{\circ} \mathrm{C}\right)$ & Experiment $\left({ }^{\circ} \mathrm{C}\right)$ \\
60 & 52.15 & 48.85 \\
55 & 50,60 & 47.47 \\
50 & 48.58 & 45,13 \\
\hline
\end{tabular}

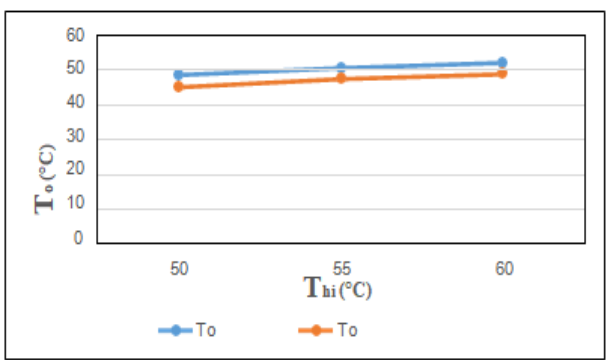

Figure 1. Comparison of Theory and Experiment on pipe 1 Counter flow

In the table and graph above, the comparison data between theory and experiment on pipe 1 for 60,55 , and $50^{\circ} \mathrm{C}$ is obtained, namely $93.7 \%, 93.8 \%$, and $92.8 \%$.

Table 3.The results of theoretical calculations and the results of the 2 Counter flow Pipe Experiment

\begin{tabular}{ccc}
\hline$\left({ }^{\circ} \mathrm{C}\right)$ & Theory $\left({ }^{\circ} \mathrm{C}\right)$ & Experiment $\left({ }^{\circ} \mathrm{C}\right)$ \\
\hline 60 & 30.45 & 34.57
\end{tabular}




\begin{tabular}{lll}
55 & 28.05 & 32.42 \\
50 & 25.99 & 29.05 \\
\hline
\end{tabular}

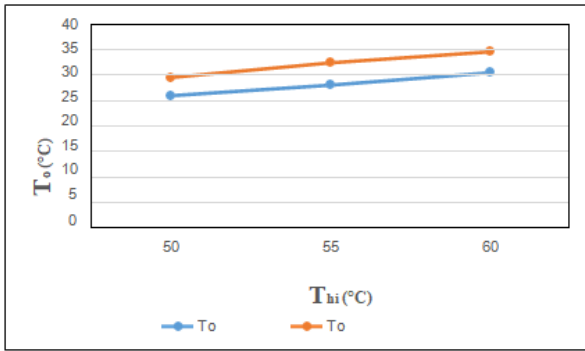

Figure 2. Comparison of Theory and Experiments on 2 Counter flow pipes

In the table and graph above, the comparison data between theory and experiment on pipe 2 for 60,55 , and $50{ }^{\circ} \mathrm{C}$ is obtained, namely $86.5 \%, 84.4 \%$, and $88.2 \%$.

Table 4. theoretical calculation results and the results of the 3 Counter flow Pipe Experiment

\begin{tabular}{ccc}
\hline$\left({ }^{\circ} \mathrm{C}\right)$ & Theory $\left({ }^{\circ} \mathrm{C}\right)$ & Experiment $\left({ }^{\circ} \mathrm{C}\right)$ \\
\hline 60 & 55.14 & 44.38 \\
55 & 52.26 & 44.57 \\
50 & 49.10 & 43.11 \\
\hline
\end{tabular}

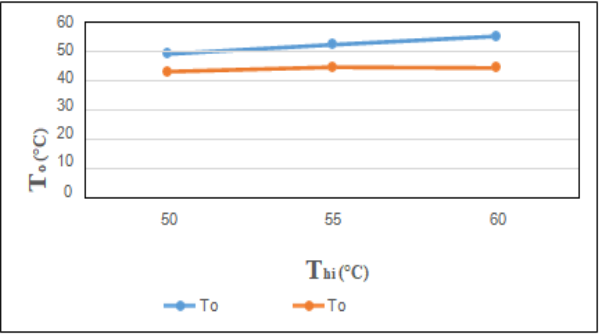

Figure 3. Comparison of Theory and Experiments on 3 Counter flow pipa pipes

In the table and graph above, the comparison data between theory and experiment on pipe 3 for 60,55 , and $50{ }^{\circ} \mathrm{C}$ is obtained, namely $80.4 \%, 85.3 \%$, and $87.8 \%$.

$=-[456.68 \times(1-0.599280)+(1193.103 \times)(0.599280)]$

$=-0.896720$

$=-[(456.68 X)(0.599280)+(1193.103 X)(0.599280)]$

$=-0.986090$

$=-[(456.68 X)(0.599280)+(1193.103 X)(1-0.599280)$

$=-0.752279$ namely:

By substituting the value of $F$ above in equations 2.33 to 2.53 , we get the values of , , and

$=55.82^{\circ} \mathrm{C}$

$=36.08^{\circ} \mathrm{C}$

$=56.56^{\circ} \mathrm{C}$

After obtaining the values of, , and, then repeat the above method for temperatures of $50^{\circ} \mathrm{C}$ and $55^{\circ} \mathrm{C}$.

\section{a. Parallel Flow Theory and Experimental Graph Analysis}

After calculating for the three variations of the hot fluid inlet, the results of these calculations can be presented in the following table: 
Table 5. Theoretical calculation results and the results of the ParallelFlow 1 Pipe Experiment

\begin{tabular}{ccc}
\hline$\left({ }^{\circ} \mathrm{C}\right)$ & Theory $\left({ }^{\circ} \mathrm{C}\right)$ & Experiment $\left({ }^{\circ} \mathrm{C}\right)$ \\
\hline 60 & 55.82 & 45.54 \\
55 & 51.94 & 44.89 \\
50 & 48.07 & 43.98 \\
\hline
\end{tabular}

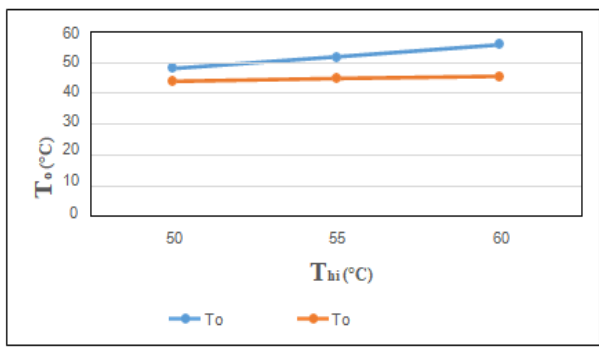

Figure 4. Comparison of Theory and Experiments on ParalleIFlow 1 pipe

In the table and graph above, the comparison data between theory and experiment on pipe 1 for 60,55 , and $50{ }^{\circ} \mathrm{C}$ is obtained, namely $81.5 \%, 86.4 \%$, and $92.5 \%$

Table 6. Theoretical calculation results and the results of the ParallelFlow 2 Pipe Experiment

\begin{tabular}{rrr}
\hline$\left({ }^{\circ} \mathrm{C}\right)$ & Theory $\left({ }^{\circ} \mathrm{C}\right)$ & Experiment $\left({ }^{\circ} \mathrm{C}\right)$ \\
\hline 60 & 36.08 & 37.78 \\
55 & 33.10 & 35.46 \\
50 & 30,12 & 33.41 \\
\hline
\end{tabular}

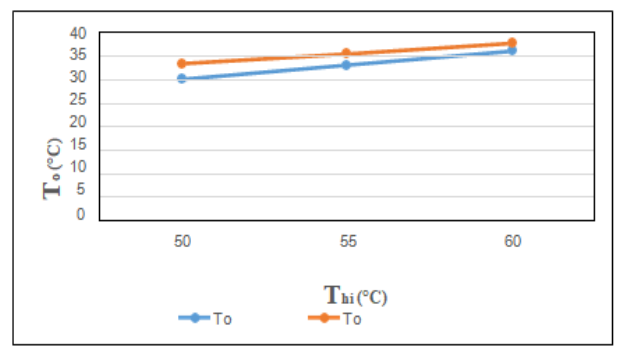

Figure 5. Comparison of Theory and Experiment on Pipe 2 Parallel Flow

In the table and graph above, the comparison data between theory and experiment on pipe 2 for 60,55 , and $50{ }^{\circ} \mathrm{C}$ is $95.2 \%, 92.8 \%$, and $89.0 \%$

Table 7. Theoretical calculation results and the results of the ParallelFlow 3 Pipe Experiment

\begin{tabular}{ccc}
\hline$\left({ }^{\circ} \mathrm{C}\right)$ & Theory $\left({ }^{\circ} \mathrm{C}\right)$ & Experiment $\left({ }^{\circ} \mathrm{C}\right)$ \\
\hline 60 & 56.56 & 42.42 \\
55 & 52.49 & 42.76 \\
50 & 48.07 & 43.08 \\
\hline
\end{tabular}




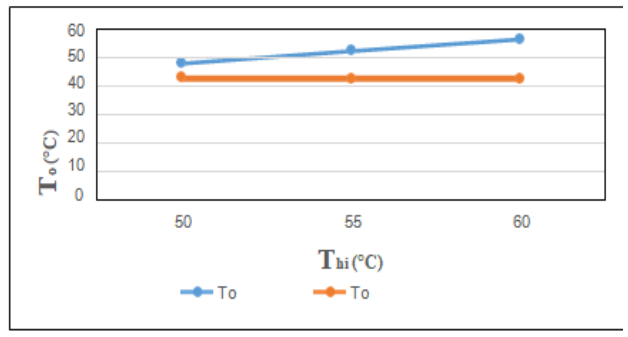

Figure 6. Comparison of Theory and Experiments on Pipe 3 Parallel Flow

In the table and graph above, the comparison data between theory and experiment on pipe 2 for 60,55 , and $50{ }^{\circ} \mathrm{C}$ is $75.0,81.4 \%$, and $89.6 \%$.

\section{b. Comparison of Counter Flow and Pararel Flow}

In the discussion above, we obtain data from theoretical calculations on counterflow and pararellflow flows where the average value of counterflow flow is smaller than that of pararellflow flow. This can be seen in the graphic image below:

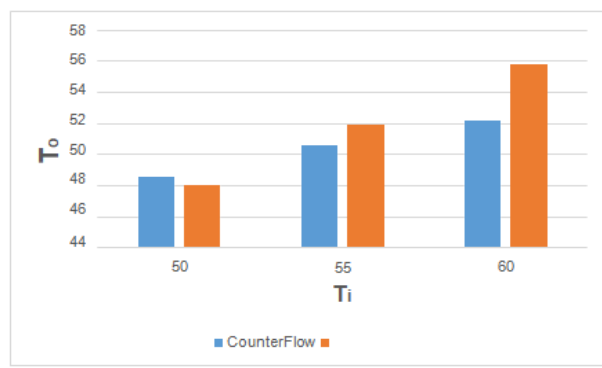

Figure 7. Comparison of Counter Flow and PararellFlow on 1 . pipe

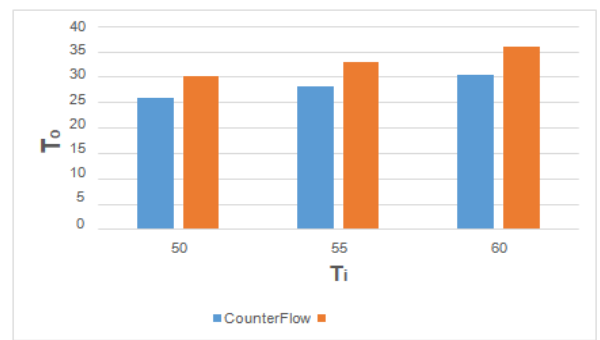

Figure 8. Comparison of Counter Flow and Pararell Flow on a 2. Pipe

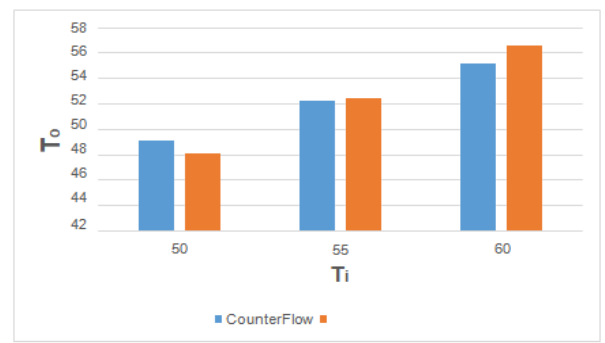

Figure 9. Comparison of CounterFlow and PararellFlow on a 3 . pipe 


\section{CONCLUSION}

The temperature of the hot fluid coming out of the APK in the experiment tends to be higher than the temperature of the hot fluid coming out of the APK in the theoretical calculations of the mathematical modeling method. Meanwhile, the temperature of the cold cold fluid coming out of the APK in the experimental tends to be lower than the temperature of the cold fluid coming out of the APK in the theoretical calculations of the mathematical modeling method.

The average difference between theoretical and experimental calculations on counter flow flow in pipe 1 is $6.6 \%$, in pipe 2 is $13.7 \%$, and in pipe 3 is $15.5 \%$. Meanwhile, the parallel flow in pipe 1 is $13.2 \%$, pipe 2 is $7.6 \%$, and pipe 3 is $18.0 \%$.

In counter flow flow, pipe 1 and pipe 3 have a smaller difference between the theoretical calculation results and experimental results compared to parallel flow flow, but for pipe 2 counter flow flow has a greater difference between theoretical calculation results and experimental results compared to parallel flow.

\section{REFERENCES}

Abdullah, Usep Mudani Karim, and Abdul Azis. "Efektifitas Strategi Pembelajaran Analisis Nilai Terhadap Pengembangan Karakter Siswa Pada Mata Pelajaran Sejarah Kebudayaan Islam." Jurnal Penelitian Pendidikan Islam,[SL] 7.1 (2019): 51-62.

Anowar Hossain, Md. 2017. Experimental Analysis of a Triple Concentric Tube Heat Exchanger. Jurnal. Universitas, Gazipur, Bangladesh.

Budiarto, Rachmawan, et al. Pengembangan UMKM Antara Konseptual dan Pengalaman Praktis. UGM PRESS, 2018.

Cengel, Yunus.A. 2003. Heat Transfer: A Practical Approach, ed. New York : McGraw-Hill.

Holman, J. P. 1997. Heat Transfer, Edisi ke-10. Jakarta :Erlangga

Incropera, F. P, dkk. Fundamentals of Heat and Mass Transfer, Edition. New York : John Wiley \& Sons

Kakac, Sadik, Hongtan Liu, dan Anchasa Pramuanjaroenkij. 2012. HEAT EXCHANGERS Selection, Rating, and Thermal Design, Third Edition. CRC Press.

Kuppan, T. 2000. Heat Exchanger Design Handbook, Second Edition.Newyork : Marcel Dekker.Inc.

Cengel, Y. A. 2006. Thermodynamics An Engineering Approach, Edition

Munson, Bruce R. 1997. Mekanika Fluida, edisi ke-2. Jakarta : Erlangga

Kreith, Frank. 1877. Principles Of Heat Transfer, ed. New York : Harper and Row.

Pitts, Donald. 2008. Perpindahan Kalor, edisi ke-2. Erlangga :2108

Prajitno, Ir., Perpindahan Kalor Lanjutan Edisi ke-2 Universitas Gadjah Mada, Yogyakarta, 2005.

Oktavianus, David, et al. "Analisis Keefektifan Alat Penukar Kalor Tabung Sepusat Aliran Berlawanan Dengan Variasi Pada Fluida Panas (Air) Dan Fluida Dingin (Metanol)." Seminar Nasional Pendidikan 2015. 2019.

Syahputra, Yogie Andrian. "Analisa Water Tube Boiler Menggunakan Thermocouple Tipe K Pt 100 Sebagai Sensor Temperature Dan Differential Pressure Dalam Proses Efesiensi Bahan Bakar Di Pt Sari Incofood Corporation."

Hundry, G. F., A. R. Trott, T. C. Welch. Tanpa Tahun. Refrigeration and Air Conditioning - Fourth Edition. B.H.

C.L. Ko dan G.L wedenkind.1995 . Analysis for optimal performance of three channel split flow heat exchanger. 
Ahmed Unal. 1998. Theoretical analysis off triple concentric-tube heat exchangers. Jurnal. Karadeniz Technical University. Trabzon. Turkey. 